\title{
Significant baseflow reduction in the Sao Francisco River Basin. Is it time to call for attention on groundwater withdrawals?
}

\author{
Murilo Lucas ${ }^{1}$, Natalya Kublik ${ }^{2}$, Dulce Rodrigues ${ }^{3}$, Antonio Meira Neto ${ }^{4}$, André Almago ${ }^{3}$, \\ Davi Melo ${ }^{5,6}$, Sam Zippper ${ }^{7}$, and Paulo Tarso Oliveira ${ }^{3}$ \\ ${ }^{1}$ Federal University of Technology - Paraná \\ ${ }^{2}$ The Polytechnic School, Arizona State University \\ ${ }^{3}$ Federal University of Mato Grosso do Sul \\ ${ }^{4}$ University of Arizona Department of Hydrology and Water Resources \\ ${ }^{5}$ Universidade Federal da Paraíba \\ ${ }^{6}$ Federal University of Paraíba \\ ${ }^{7}$ University of Kansas
}

June 15, 2020

\begin{abstract}
Water scarcity is a key challenge to global development. In Brazil, the Sao Francisco River Basin (SFB) has experienced water scarcity problems because of decreasing streamflow and increasing demands from multiple sectors (e.g., food and energy production and urban supply). However, the drivers of decreased streamflow, particularly the potential role of groundwater withdrawals, have not been yet investigated. Here, we assess long-term trends in baseflow, quickflow, and streamflow of the SFB during 1980-2015 and constrain the most likely drivers of observed decreases through trend analysis of precipitation $(P)$, evapotranspiration $(E T)$, and terrestrial water storage change $(T W S)$. We found that over $82 \%$ of the observed decrease in streamflow can be attributed to a significant decreasing baseflow trend $\left(<-20 \mathrm{~m}^{3} \mathrm{~s}^{-1} \mathrm{y}^{-1}\right)$ along the SFR with spatial agreement between decreased baseflow, increased $E T$, and irrigated agricultural land. We also found a decrease in $T W S$ across the SFB with trends exceeding $-20 \mathrm{~mm} \mathrm{y}^{-1}$. Overall, our findings indicate that decreasing groundwater contributions (i.e., baseflow) are the primary cause of the observed reduction in total SFR flow. A lack of significant climate trends indicates that climate variability likely has not caused the observed baseflow reduction, mainly in the Middle and Sub-middle SFB, and therefore groundwater and surface withdrawals may be the most likely driver of water scarcity over the SFB. We call for increased attention on groundwater's key role for the SFB and integrated regional management of surface and groundwater.
\end{abstract}

Running title: Baseflow reduction due to groundwater pumping

Murilo C. Lucas ${ }^{1}$, Natalya Kublik ${ }^{2}$, Dulce B. B. Rodrigues ${ }^{3}$, Antonio A. Meira Neto ${ }^{4}$, André Almagro ${ }^{3}$, Davi de C. D. Melo ${ }^{5}$, Samuel C. Zipper ${ }^{6}$ and Paulo Tarso S. Oliveira ${ }^{3}$

${ }^{1}$ Department of Civil Engineering, Federal University of Technology-Paraná, PR, 85502-970, Brazil. E-mail: muriloclucas@gmail.com. ORCID: https://orcid.org/0000-0002-1732-0241.

${ }^{2}$ The Polytechnic School, Arizona State University, Tempe, AZ 85212, E-mail: natalya.kublik@asu.edu. ORCID: https://orcid.org/0000-0003-0377-8750.

${ }^{3}$ Federal University of Mato Grosso do Sul, Campo Grande, MS, 79070-900, Brazil. E-mail: dulcebbr@gmail.com (https://orcid.org/0000-0001-9637-5250), andre.almagro@gmail.com (https://orcid.org/00000002-3822-4865), and paulotarsoms@gmail.com (http://orcid.org/0000-0003-2806-0083). 
${ }^{4}$ Department of Hydrology and Atmospheric Sciences, University of Arizona, Tucson, AZ 85719, USA. Email: aamneto@email.arizona.edu. ORCID: https://orcid.org/0000-0002-7508-8241.

${ }^{5}$ Department of Soils and Rural Engineering, Federal University of Paraíba, PB, 58397-000, Brazil. E-mail: melo.dcd@gmail.com. ORCID: https://orcid.org/0000-0002-0098-5095.

${ }^{6}$ Kansas Geological Survey, University of Kansas, Lawrence, KS 66047, USA. E-mail: samzipper@ku.edu. ORCID: https://orcid.org/0000-0002-8735-5757.

Corresponding author: Murilo Cesar Lucas (muriloclucas@gmail.com)

Acknowledgments and data availability: This study was supported by grants from the Ministry of Science, Technology, Innovation and Communication - MCTIC and National Council for Scientific and Technological Development - CNPq (grants 441289/2017-7 and 306830/2017-5) and Coordenação de Aperfeiçoamento de Pessoal de Nível Superior - Brasil - CAPES (Finance Code 001 and Capes PrInt). Data are available at http://doi.org/10.5281/zenodo.3887120.

Significant baseflow reduction in the Sao Francisco River Basin. Is it time to call for attention on groundwater withdrawals?

Abstract

Water scarcity is a key challenge to global development. In Brazil, the Sao Francisco River Basin (SFB) has experienced water scarcity problems because of decreasing streamflow and increasing demands from multiple sectors (e.g., food and energy production and urban supply). However, the drivers of decreased streamflow, particularly the potential role of groundwater withdrawals, have not been yet investigated. Here, we assess long-term trends in baseflow, quickflow, and streamflow of the SFB during 1980-2015 and constrain the most likely drivers of observed decreases through trend analysis of precipitation $(P)$, evapotranspiration $(\mathrm{ET})$, and terrestrial water storage change (TWS). We found that over $82 \%$ of the observed decrease in streamflow can be attributed to a significant decreasing baseflow trend $\left(<-20 \mathrm{~m}^{3} \mathrm{~s}^{-1} \mathrm{y}^{-1}\right)$ along the SFR with spatial agreement between decreased baseflow, increased ET, and irrigated agricultural land. We also found a decrease in TWS across the SFB with trends exceeding $-20 \mathrm{~mm} \mathrm{y}^{-1}$. Overall, our findings indicate that decreasing groundwater contributions (i.e., baseflow) are the primary cause of the observed reduction in total SFR flow. A lack of significant climate trends indicates that climate variability likely has not caused the observed baseflow reduction, mainly in the Middle and Sub-middle SFB, and therefore groundwater and surface withdrawals may be the most likely driver of water scarcity over the SFB. We call for increased attention on groundwater's key role for the SFB and integrated regional management of surface and groundwater.

Keywords: Groundwater pumping, streamflow depletion, trend analysis, irrigation, land use change, GRACE, water scarcity, surface-groundwater management.

\section{Introduction}

The World Economic Forum has categorized water crises as one of the top-ranked global (severe) risks since 2012 (WEF, 2019), and water is increasingly becoming a priority policy issue at global scales (Cosgrove \& Loucks, 2015). Ensuring global access to freshwater is one of the United Nations Sustainable Development Goals (SDGs) addressed in the 2030 Agenda (UN, 2015). To fulfill the 2030 Agenda, decisionmakers face the complex challenge of balancing water resource availability and water demands (Cosgrove \& Loucks, 2015; Liu et al., 2017). Unfortunately, the imbalance between water supply and demand has led to water scarcity (Van Loon \& Van Lanen, 2013). In fact, there is increasing trend in water scarcity worldwide (Kummu et al., 2016) triggered in many locations by the increase anthropogenic water use (Wada et al., 2013).

Streamflow reduction is one manifestation of water scarcity (Hoekstra, 2014). Hence, understanding how human activities alter streamflow is vital to understand and manage future water scarcity (Veldkamp et al., 2017; Vörösmarty et al., 2010). Globally, long-term annual average streamflow has decreased by $2.7 \%$, and monthly low flows have decreased, on average, by $57 \%$ on $26 \%$ of global land area because of increasing water 
abstractions and human water use (Döll, et al., 2009). Exacerbating these challenges, climate change (i.e., changes in precipitation and temperature) has also potential to alter river flow across the world (Arnell \& Gosling, 2013; Döll \& Zhang, 2010; Flörke et al., 2018; Gesualdo et al., 2019).

Water scarcity can also manifest itself in the form of persistent groundwater depletion (or overexploitation) (Gleeson et al., 2010). Persistent groundwater depletion has widely been reported in both regionally and worldwide (Castle et al., 2014; Döll et al., 2014; Famiglietti, 2014; Gleeson et al., 2012; Richey et al., 2015; Rodell et al., 2018; Rodell et al., 2009; Scanlon et al., 2012; Voss et al., 2013), and quantifying groundwater depletion has been facilitated by the advent of the Terrestrial Water Storage (TWS) product measured by the Gravity Recovery and Climate Experiment (GRACE) satellite (Lettenmaier et al., 2015). Additionally, groundwater withdrawals can decrease river flow where the stream and aquifer are hydraulically connected (Gleeson \& Richter, 2018), a phenomenon known as streamflow depletion (Barlow \& Leake, 2012; Zipper et al., 2018; Zipper et al., 2019). Globally, groundwater withdrawals are high and environmental streamflow limits are known to be severely exceeded in many locations (de Graaf et al., 2019), showing that groundwater use has increased water scarcity.

In Brazil, the Sao Francisco River Basin (SFB) has an national strategic importance due to its potential for agriculture, hydropower electricity, urban and industrial water supply and tourism (OAS/GEF/ANA, 2005). The Sao Francisco River (SFR) is popularly called "the river of national integration" because crosses a variety of biomes, climates (including the semiarid region), landscapes and socioeconomic status throughout its extension, linking the southeast and northeast Brazil. The SFR is the fourth longest river in the America Latina. The SFB has faced serious water-related problems due its water conflicts for multiple uses and particularly importance for food production by irrigation. As the interaction between surface water and groundwater has often been neglected, the Brazilian government and press have attributed the decrease in streamflow solely to natural dry weather and/or droughts over the SFB. The premise behind this argument is that low precipitation conditions are the sole driver of decreasing flow in the SFR. However, the potential impact of groundwater withdrawals within the SFB on flow in the SFR has not been evaluated.

This paper addresses some important issues pertaining to the SFR: We start by assessing whether there are significant decreases in streamflow in the SFR. After that, we investigate how different streamflow components (i.e., baseflow and/or quickflow) are related to the observed trends. Finally, we analyze the spatial and temporal patterns of climatic drivers and water storage at the SFR in order to understand the role of climate and groundwater withdrawals (demand driven) in explaining the observed trends in baseflow. Our findings represent a starting point to understand the importance of groundwater withdrawal permits over the SFB.

\section{Study area and data sources}

\subsection{Site description}

Our study area, the SFB, is challenged by water conflicts for multiple uses, with irrigation for food production representing the largest. The SFB is located in northeast Brazil and covers $639,000 \mathrm{~km}^{2}$ over seven Brazilian States: Bahia (contains $48.2 \%$ of the SFB), Minas Gerais (36.8\%), Pernambuco (10.9\%), Alagoas (2.2\%), Sergipe (1.2\%), Goias (0.5\%) and Federal District (0.2\%) (Figure 1). The SFR has a length of 2,600 km from its headwaters (northern Minas Gerais State) to estuary (between Alagoas and Sergipe States) in the Atlantic Ocean. The annual average flow and the 95 th percentile flow (i.e., $Q_{95}$ - a metric of low flows) of SFR is $2,914 \mathrm{~m}^{3} \mathrm{~s}^{-1}$ and $875 \mathrm{~m}^{3} \mathrm{~s}^{-1}$, respectively (ANA, 2018).

Irrigated agriculture is the most important economic activity in the SFB and is responsible for $86 \%$ of permitted surface water withdrawals (ANA, 2019). However, the SFR also supplies water for 16 million people in 521 municipalities (CODEVASF, 2016) and has hydroelectric power plants which supply $12 \%$ $(10,708 \mathrm{MW})$ of the installed generation capacity in the Brazil (ANA, 2013). The SFB accounts for $23 \%$ $\left(\sim 750 \mathrm{~m}^{3} \mathrm{~s}^{-1}\right)$ of all the surface water abstractions permits in Brazil (ANA, 2019).

Although the average precipitation is $938 \mathrm{~mm} \mathrm{y}^{-1}$ over the entire SFB (ANA, 2018), there is large variation 
in precipitation within the SFB (Table 1). Due to its variability in precipitation regimes and biomes, the SFB is divided into four hydrographical regions: Upper, Middle, Sub-middle, and Lower (Figure 1). The main characteristics (e.g., precipitation, climate classification and biome) of each hydrographical region are summarized in Table 1. The entire Sub-middle SFB, and most of the Lower and Middle SFB, are in the Brazilian Semiarid climate zone (Figure 1), which is considered the driest region in the country due to prolonged droughts. The spatial distribution of precipitation, evapotranspiration and climate type are shown in Figure 2.

\subsection{Streamflow data}

We obtained daily streamflow records from 20 river gauges located in the SFR over the 1980-2015 period, which we averaged to annual mean flow. The streamflow data were downloaded from the Brazilian Water Agency (ANA, Agência Nacional de Águas) website (http://www.snirh.gov.br/hidroweb/). The river gauges span the four hydrological regions as following: two gauges in the Upper SFB (40070000 and 40100000), 11 gauges in the Middle SFB (42210000, 43200000, 44200000, 44290000, 44500000, 45298000, 45480000, 46035000, 46105000, 46150000 and 46360000), three gauges in the Sub-middle SFB (48020000, 48290000 and 48590000) and four gauges in the Lower SFB (49330000, 49370000, 49660000 and 49705000).

\subsection{Precipitation, evapotranspiration and water storage change data}

To evaluate potential drivers of streamflow changes in the SFB, we computed spatiotemporal trends in water fluxes (precipitation, $P$, evapotranspiration, ET, and total water storage,TWS). We used a ground-based gridded rainfall to retrieve daily $P$ data (from 1980 to 2015) with $0.25^{\circ}$ x $0.25 \mathrm{deg}$ spatial resolution (Xavier et al., 2016). The gridded $P$ data were obtained by interpolation technique using data from $\sim 4,000$ rain gauges over the Brazil (see Xavier et al., 2016) and have been widely used in regional studies (Gadelha et al., 2019; Gomez et al., 2018; Melo et al., 2016; Melo et al., 2015).

Daily ET and potential ET (PET) was acquired from the Global Land Evaporation Amsterdam Model (GLEAM) dataset (D. G. Miralles et al., 2011), with 0.25deg x 0.25deg spatial resolution during the 19802015 period, which is available at https://www.gleam.eu/. GLEAM is dedicated to the estimation of terrestrial evaporation and root-zone soil moisture from satellite data (Martens et al., 2017). Basically, GLEAM separately derives the different components of terrestrial evaporation, i.e. transpiration (from short and tall vegetation), bare soil evaporation, open-water evaporation, interception loss, and sublimation on daily basis (D. G. Miralles et al., 2011). GLEAM has been used to evaluate trends inET at global scale (Miralles et al., 2014).

Addcionally, we analyzed monthly TWS anomaly with 1deg x 1deg spatial resolution (from mid-2002 to 2015) measured by the Gravity Recovery and Climate Experiment (GRACE) satellite mission. GRACE measures temporal variations in the Earth's gravity field, which can be used to estimate changes in TWS (i.e., surface water, snow, groundwater and soil moisture storage) (Rodell et al., 2009). GRACE-based monthly gravity products are officially processed and distributed by three processing centers: GeoforschungsZentrum Potsdam (GFZ), Jet Propulsion Laboratory (JPL) and Center for Space Research of the University of Texas at Austin (CSR). Traditionally, two approaches have been used to generate GRACE-based TWS solutions: spherical harmonics and mass concentration blocks (mascons) (Watkins et al., 2015). Here, we used JPL Release 06 (RL06) mascons solution, which is available at https://grace.jpl.nasa.gov/data/get-data/jpl_global_mascons/.

Trends in $P$, ET and TWS dataset were analyzed on annual and seasonal basis. Seasons were defined as: DJF (December, January and February), MAM (March, April and May), JJA (June, July and August) and SON (September, October and November). We used the location of groundwater wells and information about irrigation withdrawals from the Brazilian Geological Survey (CPRM). Futher, we acquired land use and land cover information over the SFB from MapBiomas Brazil Project. MapBiomas is a collaborative is a multi-institutional initiative to generate annual land cover and use maps in $30 \mathrm{~m}$ resolution using automatic classification processes applied to satellite images (MAPBIOMAS, 2020). The complete description of the MapBiomas Brazil Project and dataset can be accessed at http://mapbiomas.org. 


\section{Methods}

\subsection{Partitioning of streamflow into baseflow and quickflow}

We quantified trends in total streamflow $\left(Q_{t}\right)$, baseflow $\left(Q_{b}\right.$, representing slowly varying inputs to streamflow such as groundwater), and quickflow $\left(Q_{q}\right.$, representing quickly varying inputs to streamflow such as surface runoff). The baseflow regime was taken as representative of the overall behavior of groundwater contribution over the SFB. Digital filters have been widely used to estimate the contribution of groundwater to streamflow (Gomez et al., 2018; Nathan \& McMahon, 1990) and have been shown to compare well to alternate approaches over large spatial scales (Lott \& Stewart, 2016; Xie et al., 2020; Zhang et al., 2017). We applied two digital filters to decompose $Q_{t}$ into $Q_{b}$ and $Q_{q}$ components at daily resolution, and used the average value of $Q_{b}$ of the two filters. The $Q_{t}, Q_{b}$ and $Q_{q}$ at daily resolution was then aggregated at the annual timescale.

First, the one-parameter recursive digital filter (Lyne \& Hollick, 1979) was applied to estimate $Q_{b}$ on daily time step $(i)$ as follows:

$Q_{q_{i}}=\epsilon Q_{q_{i-1}}+\frac{1-\epsilon}{2}\left(Q_{t i}-Q_{t_{i-1}}\right)$

$Q_{b_{i}}=Q_{t_{i}}-Q_{q_{i}}$

where $\epsilon$ is the filter parameter which should assume a single value of 0.925 to generate realistic comparison to manual decomposition techniques (Arnold et al., 1995; Nathan \& McMahon, 1990).

We also applied a second, two-parameter digital filter by Eckhardt (2005) at a daily time step given by:

$Q_{b_{i}}=\frac{\left(1-\mathrm{BFI}_{\max }\right) a Q_{b_{i}-1}+(1-a) \mathrm{BFI}_{\max } Q_{t_{i}}}{1-a \mathrm{BFI}_{\max }}$

where $\mathrm{BFI}_{\max }$ is the maximum value of the baseflow index (Eq. 4) that can be modelled by Eq. (3) and $a$ is a constant (see Eckhardt, 2008). Following Eckhardt (2005), we adoptedBFI $I_{\max }=0.80$ and $a=0.98$ (i.e., perennial streams with porous aquifers).

It is important to note that filtering methods yields estimates that are not necessarily true representations of groundwater contribution, as a digital filters work by separating streamflow into fast and slow components. While groundwater systems might respond quickly to rainfall events (Wittenberg et al., 2019), which might not be captured by the filtering method, banckfull discharge originating from short-term fluctuations in surface water might be masked as a groundwater contributions (Scanlon et al., 2002). We attempt to deal with these inherent uncertainties by emplying two widely used filtering techniques.

To evaluate the role of groundwater contribution to SFR, we chose baseflow index (BFI) as hydrological signature. TheBFI represents how extensive groundwater contribution is to streamflow (Yoshida \& Troch, 2016). It was calculated as a long-term ratio between $Q_{b}$ and $Q_{t}$ (Eq. 4) at daily time step.

$\mathrm{BFI}=\frac{\sum_{i=1}^{N} Q_{b_{i}}}{\sum_{i=1}^{N} Q_{t i}}$

The BFI was calculated for each gauge. High BFIvalues $(>0.70)$ indicate that groundwater is the major contributor on streamflow (Sawicz, Wagener, Sivapalan, Troch, \& Carrillo, 2011). Conversely, low BFI values 
$(\mathrm{BFI}<0.40)$ indicate that quickflow is predominant in terms of streamflow, attesting greater surface runoff (Sawicz et al., 2011).

\subsection{Trend analysis}

We applied the Mann-Kendall (MK) trend test (using a significance level, $\alpha$, of 0.05 ) to $Q_{t}, Q_{b}$ and $Q_{q}$ on annual basis during 1980-2015. We also used the MK test to assess how the water fluxes (summarized in Table 2), might be related to the trends in total streamflow and its components. Moreover, we also used the MK test to assess water fluxes (Table 2). Trend analysis in water fluxes was performed to evaluate their potential influence on $Q_{b}$ trends.

The nonparametric MK test is widely used to describe increasing or decreasing trends in hydrological time series (Gao \& Wang, 2017). The MK test is advantageous because it does not require any assumptions regarding the distribution of the data and is not very sensitive to outliers (Hamed, 2008). Nonparametric trend tests usually require time series without autocorrelation (Bürger, 2017); that is, streamflow values must be independent each other. With regard to river flow, serial correlation is usually present, especially at daily and monthly basis (Dibike \& Solomatine, 2001). Here, we assumed that temporal dependencies are only significant at sub-annual scale (i.e., Sabzevari et al., 2015).

The MK test indicates whether changes through time are significant or not. To estimate of trend magnitude; i.e., how much the variable changes by unit of time (Drápela \& Drápelová, 2011), we used the nonparametric Theil-Sen's slope estimator (Sen, 1968; Theil, 1950). Trends were calculated for $Q_{t}, Q_{b}, Q_{q}$, and in water fluxes $(P$, ET and TWS).

4 Results

\subsection{Streamflow and baseflow spatial variation}

Figure 3 shows the distribution of annual streamflow and baseflow for river gauges over the SFB. The median $Q_{t}\left(Q_{t}\right)$ and the upper and lower bounds of the interquartile range (IQR) of $Q_{t}\left(25^{\text {th }} \leq \mathrm{IQR} \leq 75^{\text {th }}\right.$ percentile) increased moving downstream from the Upper SFB $\left(Q_{t}=195 \mathrm{~m}^{3} \mathrm{~s}^{-1} ; 154 \leq \mathrm{IQR} \leq 241 \mathrm{~m}^{3} \mathrm{~s}^{-1}\right)$, to the Middle SFB $\left(Q_{t}=1,907 \mathrm{~m}^{3} \mathrm{~s}^{-1} ; 1,505 \leq \mathrm{IQR} \leq 2,378 \mathrm{~m}^{3} \mathrm{~s}^{-1}\right)$, to the Sub-middle SFB $\left(Q_{t}=1,997 \mathrm{~m}^{3} \mathrm{~s}^{-1}\right.$; $1,745 \leq \mathrm{IQR} \leq 2,485 \mathrm{~m}^{3} \mathrm{~s}^{-1}$ ) (Figure 3). On the other hand, we observed a slight decreasing in both the 25 th percentile of $Q_{t}$ and $Q_{t}$ from the Sub-middle to the Lower SFB $\left(Q_{t}=1,920 \mathrm{~m}^{3} \mathrm{~s}^{-1} ; 1,677 \leq \mathrm{IQR} \leq 2,535\right.$ $\left.\mathrm{m}^{3} \mathrm{~s}^{-1}\right)$.

Similarly, the median $Q_{b}$ within each hydrographical region $\left(Q_{b}\right)$ followed the behavior of $Q_{t}$. That is, $Q_{b}$ increased from the Upper SFB $\left(Q_{b}=161 \mathrm{~m}^{3} \mathrm{~s}^{-1} ; 125 \leq I Q R \leq 198 \mathrm{~m}^{3} \mathrm{~s}^{-1}\right)$ to the Middle SFB $\left(Q_{b}=1,588\right.$ $\left.\mathrm{m}^{3} \mathrm{~s}^{-1} ; 1,232 \leq I Q R \leq 1,996 \mathrm{~m}^{3} \mathrm{~s}^{-1}\right)$ to the Sub-middle SFB $\left(Q_{b}=1,669 \mathrm{~m}^{3} \mathrm{~s}^{-1} ; 1,465 \leq I Q R \leq 2,115 \mathrm{~m}^{3}\right.$ $\mathrm{s}^{-1}$ ) (Figure 3). However, it is interesting that the increased $Q_{b}$ from the Middle to the Sub-middle SFB was quite small. Further, we found a slight decreased regime in both $Q_{b}$ and the $25^{\text {th }}$ percentile of $Q_{b}$ from the Sub-middle to the Lower SFB $\left(Q_{b}=1,638 \mathrm{~m}^{3} \mathrm{~s}^{-1} ; 1,420 \leq I Q R \leq 2,168 \mathrm{~m}^{3} \mathrm{~s}^{-1}\right)$.

Baseflow, representing slowly varying water sources such as groundwater contributions, accounts for the large majority of $Q_{t}$ in all hydrographical regions of the SFB. BFI for all gages exceeded 0.8 , with relatively little difference in BFI among gages (Table 2). The highest and lowest value of BFI were observed in the Sub-middle and the Upper SFB, respectively (Table 2). In general, the BFI tended to increase from the Upper to Lower SFB.

\subsection{Trends in streamflow, baseflow and quickflow}

In general, we found a significant decreasing trend in $Q_{t}, Q_{b}$, and $Q_{q}$ (at $\alpha=0.05$ ) over the SFB during 1980-2015 (Table 2). Trends in the two gauges located in the Upper SFB were not significant, while all other gages had significant decreasing trends for all components of flow. Averaged over all gages, $Q_{b}$ in the SFB is 
decreasing at a rate of $-26.12 \mathrm{~m}^{3} \mathrm{~s}^{-1} \mathrm{y}^{-1}(1980-2015)$. The trend magnitude in $Q_{b}$ varied from -11.91 to -30.63 $\mathrm{m}^{3} \mathrm{~s}^{-1} \mathrm{y}^{-1}$ over the Middle SFB, from -23.89 to $-26.27 \mathrm{~m}^{3} \mathrm{~s}^{-1} \mathrm{y}^{-1}$ over the Sub-middle SFB and from -32.78 to $23.71 \mathrm{~m}^{3} \mathrm{~s}^{-1} \mathrm{y}^{-1}$ over the Lower SFB (Table 2). Moving from the SFB to the outlet, trend magnitude became significantly more negative. Overall, the trends observed in $Q_{b}$ explain the large majority (82\%) of the observed trends in $Q_{t}$, indicating that observed decreases in streamflow can be primarily be attributed to changing baseflow conditions.

Similar to trends in $Q_{t}$ and $Q_{b}$, significant decreases in $Q_{q}$ were found throughout the SFB (Table 2). Trend magnitude in $Q_{q}$ ranged from -3.19 to $-5.69 \mathrm{~m}^{3} \mathrm{~s}^{-1} \mathrm{y}^{-1}$ in the Middle, from -5.71 to $6.55 \mathrm{~m}^{3} \mathrm{~s}^{-1} \mathrm{y}^{-1}$ in the Submiddle, and between -5.65 and $-7.23 \mathrm{~m}^{3} \mathrm{~s}^{-1} \mathrm{y}^{-1}$ in the Lower SFB. Overall, trend magnitude in $Q_{q}$ became more negative from the Middle to Sub-middle and Lower SFB.

\subsection{Trends in precipitation, evapotranspiration and water storage changes}

The annual $P$ and ET were not significant (at $\alpha=0.05$ ) over most of the SFB during 1980-2015 (Figure $4 \mathrm{c}, \mathrm{d})$. Nevertheless, a significant decreasing trend in annual $P$ was observed in few regions over the western Middle SFB, specifically next to the western edge of the basin (Figure 4c) which is a region with widespread irrigation (Figure $4 \mathrm{~b}$ ). In addition, annual ETtended to decrease in few regions over central and western part of the Middle SFB and in the Upper SFB (Figure 4d). We also noted a significant negative trend in TWS over almost the SFB, mainly over Middle SFB (Figure 4e). On the other hand, a nonsignificant trend in TWS was noted in the Lower SFB (Figure 4e).

One should note the overlap between regions with decreasing $P$ andTWS, decreasing $Q_{b}$, and increasing ET in the Middle SFB, which has most irrigated agriculture in the region (Figure 4b-e). A strong trend magnitude in TWS of $-2.3 \mathrm{~mm} \mathrm{y}^{-1}$ occurred in the Middle SFB around the SFR channel path near regions with large irrigation withdrawals (Figure 4b,e). Furthermore, we noted some regions with a significant decreasing trend in TWS (-1.4 [?] TWS [?] -0.5 $\mathrm{mm} \mathrm{y}^{-1}$; Figure 4e) over the Sub-middle SFB, which has a large number of irrigation wells (Figure 4a). However, information about the water demand and purpose of individual wells (e.g., irrigation and urban supply system) were not available. Moreover, although these wells are documented we cannot identify which ones were in operation.

The seasonal analysis revealed an overall nonsignificant trend in Pover the SFB (Figure 5a-d). The exception is a strong decreasing in $P\left(-12\right.$ [?] $P$ [?] $\left.-1.0 \mathrm{~mm} \mathrm{y}^{-1}\right)$ over the western Middle SFB during DJF season (Figure 5a). In addition, the $P$ also tended to increase $\left(P=9 \mathrm{~mm} \mathrm{y}^{-1}\right)$ strongly in a few regions over and adjacent to the Lower SFB during JJA season (Figure 5c). Thus, in general, the seasonal $P$ results indicate that the decreases in annual $P$ are primarily driven by reductions in summer (DJF) precipitation.

We found a remarkable increasing trend in seasonal ET (3.0 [?]ET [?] $0.5 \mathrm{~mm} \mathrm{y}^{-1}$ ) specifically in the heavilyirrigated west and central parts of the Middle SFB in the MAM season (Figure 5f). The seasonal ET tended to increase by up to $1.0 \mathrm{~mm} \mathrm{y}^{-1}$ during DJF (Figure 5e). Conversely, results show a slight decreasing trend in ET (-1 [?]ET [?] -3.0 $\left.\mathrm{mm} \mathrm{y}^{-1}\right)$ during SON season over the western Middle SFB. Additionally, in general, nonsignificant trend in seasonal ET was observed in the Upper, Sub-middle and Lower SFB.

With regard to TWS, we noted a negative trend in the western and eastern Middle SFB during all seasons (Figure 5i-l) where there are large irrigation demand and wells (Figure 4a,b). For instance, the strongest seasonal decreasing trend (-40 [?] TWS [?] $\left.-20 \mathrm{~mm} \mathrm{y}^{-1}\right)$ overlapped the agricultural irrigation land over the western and central Middle SFB in MAM and JJA (Figure 5j,k). Furthermore, TWS significantly increased from JJA to SON and DJF season in the Centre-West and Centre-East of Middle SFB. Conversely, there was a nonsignificant seasonal trend in the Upper, Sub-middle and Lower SFB.

\section{Discussion}

The partitioning of total streamflow into baseflow and quickflow components reveals the major role of groundwater in sustaining the Sao Francisco River discharge. Our results show a strong decreasing trend in baseflow over almost the entire SFB (Table 2), most prominently in the heavily-irrigated Middle SFB, and that baseflow reductions are the primary driver of observed change in total streamflow. The Upper SFB is 
the only region that presented nonsignificant trends in baseflow during the 1980-2015 period. These results suggest that groundwater withdrawals for irrigation may be the most likely driver responsible for decreased baseflow in the Middle SFB and downstream areas. This is supported by the spatial correspondence between irrigated agricultural land (Figure 4b), a decreasing trend in TWS (Figure 5i-1), and a strong increasing trend in ET (Figure 5f,g). While there are many irrigation wells in this region (Figure 4a), we do not have data on direct surface water withdrawals from the SFR, which may also contribute to strong decreasing trend in $Q_{b}$ near the irrigated land (Figure 4e).

The close relation between increased ET and decreased Pover the irrigated area (i.e., Centre-West part of the Middle SFB, which comprises the MATOPIBA region) can be related to deforestation for agricultural cropping. MATOPIBA is located mainly in the Bahia and Tocantins States with irrigated holdings larger than 5,000 ha and water demand is greater than $100 \mathrm{~L} \mathrm{~s}^{-1}$ (Oliveira et al., 2019). MATOPIBA experienced significant expansion of the irrigated agriculture by center pivots from 13 to 1,548 pivots during 1980-2015 (Landau et al., 2016). Hence, given the expansion of agricultural land over the Middle SFB from 1985 to 2015 (Figure 6), these lines of evidence combine to suggest that irrigated agricultural expansion induced an increase in groundwater withdrawals, and consequently the increase trend in ET during DJF and MAM. These withdrawals lead to a net increase in water export to the atmosphere (increasedET), decreasing TWS, and ultimately decreases in baseflow over the Middle SFB. This problem mirrors the challenges of diverse settings such as the United States, India, and China where marked increases in groundwater-fed irrigation in the last few decades have lowered groundwater levels and reduced streamflow (Kustu et al., 2010; Scanlon et al., 2007).

The observed decrease in ET during SON season may be explained by the harvesting of different crops, mainly maize (known as "safrinha"), sugarcane and wheat (CONAB, 2015). This raises the possibility that the harvest of crops may trigger a deforestation-induced feedback phenomena in which reduced ET can further reduce $P$, as has been demonstrated in the Amazon forest (i.e., Zemp et al., 2017). This is corroborated by the increasedTWS from MAM and JJA to SON and DJF period, indicating more infiltration, and eventually groundwater recharge. These results agreeded with those reported by Oliveira et al. (2019; 2014). Although this area also comprises rain-fed agriculture, irrigation is often required during dry periods. Unfortunately, data are not available on the seasonal distribution of groundwater and surface water withdrawals.

The decrease in baseflow can be partly related to groundwater irrigation from the Urucuia Aquifer System (UAS). The UAS is an sedimentary aquifer that covers an area of $125,000 \mathrm{~km}^{2}$ and is an important source of water to the SFR, especially during dry seasons (Goncalves et al., 2020). The UAS is located in most part over the western Bahia State by the left bank of SFR and covers the MATOPIBA region. On average, the UAS discharged $792 \mathrm{~m}^{3} \mathrm{~s}^{-1}$ to the SFR in 1980, however this contribution has decreased continuously to $390 \mathrm{~m}^{3} \mathrm{~s}^{-1}$ in 2015 (Goncalves et al., 2018). In addition, previous studies showed that groundwater storage tended to decrease in $-6.5+-2.6 \mathrm{~mm} \mathrm{y}^{-1}\left(9.75 \mathrm{~km}^{3}\right)$ in the UAS over the 2003-2014 period (Goncalves et al., 2020). Therefore, given the importance of the UAS, it is reasonable to infer that groundwater decline in the UAS may have affected the SFR flow, particularly in the Middle SFB, during the 1980-2015 period.

In the Sub-middle SFB, it is likely that baseflow reduction is driven by combined surface and groundwater withdrawals. Annual decreasing trend inTWS occurred only in the Centre-North part of Sub-middle (near the SFR) and was lower related to the Middle SFB. This indicated that the surface water withdrawals for irrigation may be responsible for the lack of TWS trends in the regions south of the SFR in the Sub-middle SFB. The Sub-middle SFB has been subjected to expansion of irrigated agriculture (Figure 6), primarily vineyards and mango orchards in the Juazeiro (Bahia State) and Petrolina city (Pernambuco State) (Andrade et al., 2017). To carry out the irrigated expansion in this region, the undisturbed vegetation (Caatinga) have been replaced by vineyards (Preston et al., 2017). Since mango orchards and vineyards are perennial fruit crops, irrigation from surface and/or groundwater is needed during dry periods. Teixeira et al. (2010) reported the impact of replacing Caatinga to vineyards and mango orchard on ET over the Sub-middle SFB. They concluded that ET increased by 2 and 3 times for vineyards $\left(450-800 \mathrm{~mm} \mathrm{y}^{-1}\right)$ and mango orchand (500$1,300 \mathrm{~mm} \mathrm{y}^{-1}$ ), respectively, in comparison with the Caatinga vegetation $\left(200-400 \mathrm{~mm} \mathrm{y}^{-1}\right.$ ) in 2006 (Teixeira, 
2010). However, we surprisingly found a nonsignificant trend in ET over the Sub-middle SFB (Figure 4,5). This may occured due to the long-term (average) relation between ET, potential evapotranspiration (PET) and $P$. Using the Budyko framework (Budyko, 1974), we find that ET is water-limited by the dry climate (i.e., high temperature and solar radiation) over the Sub-middle SFB (Figure 7). As consequence, significant trends in ET were not detected even with the increased ET after replacing Caatinga vegetation by vineyards and mango orchard. Therefore, it is reasonable to infer that the climatic condition (i.e., $P<E T<P E T$ ) may be another responsible to the decrease trend inTWS in these regions.

However, according to Figure 7 other factors like surface and groundwater withdrawls may explain observed departures from observed streamflow against the Budyko curve. The streamflow depletion we describe above causes $E T$ to be overestimated when calculated as $Q_{t}$ minus $P$ following the Budyko framework, leading to the points shifted upwards above the Budyko curve (Figure 7). Further, climate variability (i.e., $P$ andET) may overlap the effect of groundwater withdrawals during the study period, making it difficult to evaluate them separately (see Gleeson and Richter, 2018).

6 Conclusion

Decreasing streamflow has brought a major concern about water security worldwide, especially in (semi)arid regions. In Brazil, the Sao Francisco Basin (SFB) has experienced water-related problems because of decreased flow in Sao Francisco River (SFR). The SFB is strategically important for national food and energy production with a huge irrigated area, and a population of 16 million. These multiple water demands make the SFR a socio-economically important region and balancing their needs poses a difficult task for decisionmakers. Because the Brazilian government has encouraged the expansion of irrigated agriculture to increase food production, we further expect increased water demand and conflict in the future of the SFB (Multsch et al., 2020).

Although previous studies have focused on the impacts of climate variability on decreasing SFR flow, none has addressed the possible influence of groundwater withdrawals. Here, we provide the first overview of long-term change in relevant hydrological fluxes (i.e., precipitation, evapotranspiration, baseflow and water storage) to constrain potential drivers of the observed decrease in SFR flow. Our findings suggest that significant decreases in SFR flow are primarily due to reduced groundwater contributions to total streamflow (as baseflow) during the 1980-2015 period. While no long-term groundwater use data are available for the region, this suggests that groundwater withdrawals may be the most likely driver of the observed negative trend in the SFR baseflow, which is compounded by direct surface water withdrawals. Further investigation is necessary to precisely identify the causes of decreased baseflow and relative importance of different drivers.

Combined, these results indicate that river water and groundwater are hydraulically connected in the SFB, and that groundwater pumping can decrease flow in the SFR. Therefore, we call for increased attention on groundwater management in the SFB, especially in the most heavily-irrigated Middle SFB region. As irrigated agricultural will likely continue to expand and require more water, groundwater will play a key role for future food production. This study demonstrates that decisionmakers should adopt integrated surface and groundwater management strategies.

References

ANA - Agencia Nacional de Aguas. (2013). Sala de Situacao da Agencia Nacional de Aguas. Retrieved April 13, 2020, from Sala de Situacao da Agencia Nacional de Aguas website: https://www.ana.gov.br/salade-situacao/sao-francisco/sao-francisco-saiba-mais

ANA - Agencia Nacional de Aguas. (2015). Conjuntura dos recursos hidricos: informe 2015 . Retrieved from http://www.snirh.gov.br/portal/snirh/centrais-de-conteudos/conjuntura-dos-recursos-hidricos

ANA - Agencia Nacional de Aguas. (2018). Brazilian Water Resources Report-201\%: Full Report. Retrieved from http://conjuntura.ana.gov.br/

ANA - Agencia Nacional de Aguas. (2019). Conjuntura dos recursos hidricos no Brasil 2019: informe an- 
ual . Retrieved from http://www.snirh.gov.br/portal/snirh/centrais-de-conteudos/conjuntura-dos-recursoshidricos

Andrade, V. P. M., da Silva, J. A. B., de Sousa, J. S. C., Oliveira, F. F., \& Simoes, W. L. (2017). Aspectos fisiologicos de videira submetida a manejos de irrigacao e fertilizacao. Pesquisa Agropecuaria Tropical , 47 (4), 390-398. https://doi.org/10.1590/1983-40632017v4748640

Arnell, N. W., \& Gosling, S. N. (2013). The impacts of climate change on river flow regimes at the global scale. Journal of Hydrology ,486 , 351-364. https://doi.org/10.1016/j.jhydrol.2013.02.010

Arnold, J. G., Allen, P. M., Muttiah, R., \& Bernhardt, G. (1995). Automated Base Flow Separation and Recession Analysis Techniques.Ground Water , 33 (6), 1010-1018. https://doi.org/10.1111/j.17456584.1995.tb00046.x

Barlow, P. M., \& Leake, S. A. (2012). Streamflow depletion by wells-Understanding and managing the effects of groundwater pumping on streamflow . Retrieved from https://pubs.usgs.gov/circ/1376/

Budyko, M. I. (1974). Climate and life. New York: Academic Press.

Burger, G. (2017). On trend detection. Hydrological Processes ,31 (22), 4039-4042. https://doi.org/10.1002/hyp.11280

Castle, S. L., Thomas, B. F., Reager, J. T., Rodell, M., Swenson, S. C., \& Famiglietti, J. S. (2014). Groundwater depletion during drought threatens future water security of the Colorado River Basin.Geophysical Research Letters , 41 (16), 5904-5911. https://doi.org/10.1002/2014GL061055

CBHSF - Comite da Bacia Hidrografica do Rio Sao Francisco. (2020).Plano de Recursos Hidricos da Bacia Hidrografica do Rio Sao Francisco 2016-2025 . Retrieved from https://cbhsaofrancisco.org.br/documentacao/plano-de-recursos-hidricos-2016-2025/

CODEVASF - Companhia de Desenvolvimento dos Vales dSao Francisco e do Parnaiba. (2016). Plano nascente Sao Francisco: : plano de preservacao e recuperacao de nascentes da bacia do rio Sao Francisco(E. J. de O. Motta \& N. E. W. Goncalves, Eds.). Brasilia: Editora iABS.

CONAB - Companhia Nacional de Abastecimento. (2015).Acompanhamento da safra brasileira de graos, $v$. 2 - Safra 2014/15, n. 10 . Retrieved from http://www.conab.gov.br

Cosgrove, W. J., \& Loucks, D. P. (2015). Water management: Current and future challenges and research directions. Water Resources Research , 51 (6), 4823-4839. https://doi.org/10.1002/2014WR016869

de Graaf, I. E. M., Gleeson, T., (Rens) van Beek, L. P. H., Sutanudjaja, E. H., \& Bierkens, M. F. P. (2019). Environmental flow limits to global groundwater pumping. Nature , 574 (7776), 90-94. https://doi.org/10.1038/s41586-019-1594-4

Dibike, Y. B., \& Solomatine, D. P. (2001). River flow forecasting using artificial neural networks. Physics and Chemistry of the Earth, Part B: Hydrology, Oceans and Atmosphere , 26 (1), 1-7. https://doi.org/10.1016/S1464-1909(01)85005-X

Doll, P., Fiedler, K., \& Zhang, J. (2009). Global-scale analysis of river flow alterations due to water withdrawals and reservoirs.Hydrology and Earth System Sciences , 13 (12), 2413-2432. https://doi.org/10.5194/hess-13-2413-2009

Doll, P., \& Zhang, J. (2010). Impact of climate change on freshwater ecosystems: a global-scale analysis of ecologically relevant river flow alterations. Hydrology and Earth System Sciences , 14 (5), 783-799. https://doi.org/10.5194/hess-14-783-2010

Doll, Petra, Muller Schmied, H., Schuh, C., Portmann, F. T., \& Eicker, A. (2014). Global-scale assessment of groundwater depletion and related groundwater abstractions: Combining hydrological modeling with 
information from well observations and GRACE satellites. Water Resources Research , 50 (7), 5698-5720. https://doi.org/10.1002/2014WR015595

Drapela, K., \& Drapelova, I. (2011). Application of Mann-Kendall test and the Sen's slope estimates for trend detection in deposition data from Bily Kriz (Beskydy Mts., the Czech Republic) 1997-2010.

Eckhardt, K. (2005). How to construct recursive digital filters for baseflow separation. Hydrological Processes , 19 (2), 507-515. https://doi.org/10.1002/hyp.5675

Eckhardt, K. (2008). A comparison of baseflow indices, which were calculated with seven different baseflow separation methods. Journal of Hydrology , 352 (1-2), 168-173. https://doi.org/10.1016/j.jhydrol.2008.01.005

Famiglietti, J. S. (2014). The global groundwater crisis. Nature Climate Change , 4 (11), 945-948. https://doi.org/10.1038/nclimate2425

Flörke, M., Schneider, C., \& McDonald, R. I. (2018). Water competition between cities and agriculture driven by climate change and urban growth. Nature Sustainability , 1 (1), 51-58. https://doi.org/10.1038/s41893017-0006-8

Gadelha, A. N., Coelho, V. H. R., Xavier, A. C., Barbosa, L. R., Melo, D. C. D., Xuan, Y., .. Almeida, C. das N. (2019). Grid box-level evaluation of IMERG over Brazil at various space and time scales.Atmospheric Research , 218 , 231-244. https://doi.org/10.1016/j.atmosres.2018.12.001

Gao, T., \& Wang, H. (2017). Trends in precipitation extremes over the Yellow River basin in North China: Changing properties and causes.Hydrological Processes , 31 (13), 2412-2428. https://doi.org/10.1002/hyp.11192

Gesualdo, G. C., Oliveira, P. T., Rodrigues, D. B. B., \& Gupta, H. V. (2019). Assessing water security in the S\&amp;amp;\#227;o Paulo metropolitan region under projected climate change. Hydrology and Earth System Sciences , 23 (12), 4955-4968. https://doi.org/10.5194/hess-23-4955-2019

Gleeson, T., \& Richter, B. (2018). How much groundwater can we pump and protect environmental flows through time? Presumptive standards for conjunctive management of aquifers and rivers. River Research and Applications , 34 (1), 83-92. https://doi.org/10.1002/rra.3185

Gleeson, Tom, VanderSteen, J., Sophocleous, M. A., Taniguchi, M., Alley, W. M., Allen, D. M., \& Zhou, Y. (2010, June). Groundwater sustainability strategies. Nature Geoscience , Vol. 3, pp. 378-379. https://doi.org/10.1038/ngeo881

Gleeson, Tom, Wada, Y., Bierkens, M. F. P., \& Van Beek, L. P. H. (2012). Water balance of global aquifers revealed by groundwater footprint. Nature , 488 (7410), 197-200. https://doi.org/10.1038/nature11295

Gómez, D., Melo, D. C. D., Rodrigues, D. B. B., Xavier, A. C., Guido, R. C., \& Wendland, E. (2018). Aquifer Responses to Rainfall through Spectral and Correlation Analysis. JAWRA Journal of the American Water Resources Association , 54 (6), 1341-1354. https://doi.org/10.1111/1752-1688.12696

Gonçalves, Roger D., Stollberg, R., Weiss, H., \& Chang, H. K. (2020). Using GRACE to quantify the depletion of terrestrial water storage in Northeastern Brazil: The Urucuia Aquifer System. Science of the Total Environment , 705 , 135845. https://doi.org/10.1016/j.scitotenv.2019.135845

Gonçalves, Roger Dias, Engelbrecht, B. Z., \& Chang, H. K. (2018). Evolução da contribuição do Sistema Aquífero Urucuia para o Rio São Francisco, Brasil. Águas Subterrâneas , 32 (1), 1-10. https://doi.org/10.14295/ras.v32i1.28916

Hamed, K. H. (2008). Trend detection in hydrologic data: The Mann-Kendall trend test under the scaling hypothesis. Journal of Hydrology , 349 (3-4), 350-363. https://doi.org/10.1016/j.jhydrol.2007.11.009 
Hoekstra, A. Y. (2014, April 25). Water scarcity challenges to business.Nature Climate Change, Vol. 4, pp. 318-320. https://doi.org/10.1038/nclimate2214

IBGE - Instituto Brasileiro de Geografia e Estatística. (2010). Censo demográfico. Retrieved June 9, 2020, from https://censo2010.ibge.gov.br/

Kummu, M., Guillaume, J. H. A., De Moel, H., Eisner, S., Flörke, M., Porkka, M., .. Ward, P. J. (2016). The world's road to water scarcity: Shortage and stress in the 20th century and pathways towards sustainability. Scientific Reports , 6 (1), 1-16. https://doi.org/10.1038/srep38495

Kustu, M. D., Fan, Y., \& Robock, A. (2010). Large-scale water cycle perturbation due to irrigation pumping in the US High Plains: A synthesis of observed streamflow changes. Journal of Hydrology ,390 (3-4), 222-244. https://doi.org/10.1016/j.jhydrol.2010.06.045

Landau, E. C., Guimarães, D. P., \& Sousa, D. L. de. (2016).Expansão geográfica da agricultura irrigada por pivôs centrais na Região do Matopiba entre 1985 e 2015 (1th ed.; E. C. Landau, Ed.). Sete Lagoas: Embrapa Milho e Sorgo.

Lettenmaier, D. P., Alsdorf, D., Dozier, J., Huffman, G. J., Pan, M., \& Wood, E. F. (2015). Inroads of remote sensing into hydrologic science during the WRR era. Water Resources Research , 51 (9), 7309-7342. https://doi.org/10.1002/2015WR017616

Liu, J., Yang, H., Gosling, S. N., Kummu, M., Flörke, M., Pfister, S., .. Oki, T. (2017, June 1). Water scarcity assessments in the past, present, and future. Earth's Future, Vol. 5, pp. 545-559. https://doi.org/10.1002/2016EF000518

Lott, D. A., \& Stewart, M. T. (2016). Base flow separation: A comparison of analytical and mass balance methods. Journal of Hydrology , 535 , 525-533. https://doi.org/10.1016/j.jhydrol.2016.01.063

Lyne, L. D., \& Hollick, M. (1979). Stochastic time-variable rainfall runoff modelling. Hydrology and Water Resources Symposium , 89-92. Perth, Australia: Institution of Engineers Australia.

MAPBIOMAS. (2020). Project MapBiomas - Collection 3.0 of Brazilian Land Cover \& Use Map Series. Retrieved June 9, 2020, from https://mapbiomas.org/

Martens, B., Miralles, D. G., Lievens, H., van der Schalie, R., de Jeu, R. A. M., Fernández-Prieto, D., ... Verhoest, N. E. C. (2017). GLEAM v3: satellite-based land evaporation and root-zone soil moisture. Geoscientific Model Development , 10 (5), 1903-1925. https://doi.org/10.5194/gmd-10-1903-2017

Melo, D. de C. D., Scanlon, B. R., Zhang, Z., Wendland, E., \& Yin, L. (2016). Reservoir storage and hydrologic responses to droughts in the Paraná River basin, south-eastern Brazil. Hydrology and Earth System Sciences , 20 (11), 4673-4688. https://doi.org/10.5194/hess-20-4673-2016

Melo, D. de C. D., Xavier, A. C., Bianchi, T., Oliveira, P. T. S., Scanlon, B. R., Lucas, M. C., \& Wendland, E. (2015). Performance evaluation of rainfall estimates by TRMM Multi-satellite Precipitation Analysis 3B42V6 and V7 over Brazil. Journal of Geophysical Research: Atmospheres , 120 (18), 9426-9436. https://doi.org/10.1002/2015JD023797

Miralles, D. G., Holmes, T. R. H., De Jeu, R. A. M., Gash, J. H., Meesters, A. G. C. A., \& Dolman, A. J. (2011). Global land-surface evaporation estimated from satellite-based observations. Hydrology and Earth System Sciences , 15 (2), 453-469. https://doi.org/10.5194/hess-15-453-2011

Miralles, Diego G., Van Den Berg, M. J., Gash, J. H., Parinussa, R. M., De Jeu, R. A. M., Beck, H. E., ... Johannes Dolman, A. (2014). El Nino-La Nina cycle and recent trends in continental evaporation. Nature Climate Change , 4 (2), 122-126. https://doi.org/10.1038/nclimate2068

MMA - Ministerio do Meio Ambiente. (2006). Caderno da Regiao Hidrografica do Sao Francisco . Retrieved from www.mma.gov.br 
Multsch, S., Krol, M. S., Pahlow, M., Assuncao, A. L. C., Barretto, A. G. O. P., de Jong van Lier, Q., \& Breuer, L. (2020). Assessment of potential implications of agricultural irrigation policy on surface water scarcity in Brazil. Hydrology and Earth System Sciences ,24 (1), 307-324. https://doi.org/10.5194/hess-24$307-2020$

Nathan, R. J., \& McMahon, T. A. (1990). Evaluation of automated techniques for base flow and recession analyses. Water Resources Research , 26 (7), 1465-1473. https://doi.org/10.1029/WR026i007p01465

OAS/GEF/ANA. (2005). Sao Francisco River Basin - Integrated Management of Land Based Activitiesin the Sao Francisco River Basin . Retrieved from http://www.oas.org/DSD/WaterResources/Publications_eng.htm

Oliveira, P. T. S., Almagro, A., Colman, C., Kobayashi, Alex. N. A. Rodrigues, D. B. B., Meira Neto, A. A., \& Gupta, H. V. (2019). Nexus of water-food-energy-ecosystem services in the Brazilian Cerrado. In C. A. Silva, R. C. V. Tucci, C. E. M. Scott (Ed.), Water and Climate modeling in large basins 5 (5th ed., pp. 7-30). Porto Alegre: ABRHidro.

Oliveira, Paulo Tarso S., Nearing, M. A., Moran, M. S., Goodrich, D. C., Wendland, E., \& Gupta, H. V. (2014). Trends in water balance components across the Brazilian Cerrado. Water Resources Research ,50 (9), 7100-7114. https://doi.org/10.1002/2013WR015202

Preston, W., do Nascimento, C. W. A., da Silva, Y. J. A. B., Silva, D. J., \& Ferreira, H. A. (2017). Soil fertility changes in vineyards of a semiarid region in Brazil. Journal of Soil Science and Plant Nutrition, 17 (3), 672-685. https://doi.org/10.4067/S0718-95162017000300010

Richey, A. S., Thomas, B. F., Lo, M., Reager, J. T., Famiglietti, J. S., Voss, K., ... Rodell, M. (2015). Quantifying renewable groundwater stress with GRACE. Water Resources Research , 51 (7), 5217-5238. https://doi.org/10.1002/2015WR017349

Rodell, M., Famiglietti, J. S., Wiese, D. N., Reager, J. T., Beaudoing, H. K., Landerer, F. W., \& Lo, M. H. (2018). Emerging trends in global freshwater availability. Nature , 557 (7707), 651-659. https://doi.org/10.1038/s41586-018-0123-1

Rodell, Matthew, Velicogna, I., \& Famiglietti, J. S. (2009). Satellite-based estimates of groundwater depletion in India.Nature , 460 (7258), 999-1002. https://doi.org/10.1038/nature08238

Sabzevari, A. A., Zarenistanak, M., Tabari, H., \& Moghimi, S. (2015). Evaluation of precipitation and river discharge variations over southwestern Iran during recent decades. Journal of Earth System Science, 124 (2), 335-352. https://doi.org/10.1007/s12040-015-0549-x

Sawicz, K., Wagener, T., Sivapalan, M., Troch, P. A., \& Carrillo, G. (2011). Catchment classification: empirical analysis of hydrologic similarity based on catchment function in the eastern USA.Hydrology and Earth System Sciences , 15 (9), 2895-2911. https://doi.org/10.5194/hess-15-2895-2011

Scanlon, B. R., Faunt, C. C., Longuevergne, L., Reedy, R. C., Alley, W. M., McGuire, V. L., \& McMahon, P. B. (2012). Groundwater depletion and sustainability of irrigation in the US High Plains and Central Valley.Proceedings of the National Academy of Sciences of the United States of America , 109 (24), 93209325. https://doi.org/10.1073/pnas.1200311109

Scanlon, B. R., Healy, R. W., \& Cook, P. G. (2002). Choosing appropriate techniques for quantifying groundwater recharge.Hydrogeology Journal , 10 (1), 18-39. https://doi.org/10.1007/s10040-001-0176-2

Scanlon, B. R., Jolly, I., Sophocleous, M., \& Zhang, L. (2007). Global impacts of conversions from natural to agricultural ecosystems on water resources: Quantity versus quality. Water Resources Research, 43 (3). https://doi.org/10.1029/2006WR005486

Sen, P. K. (1968). Estimates of the Regression Coefficient Based on Kendall's Tau. Journal of the American Statistical Association ,63 (324), 1379-1389. https://doi.org/10.1080/01621459.1968.10480934 
Teixeira, A. H. de C. (2010). Determining Regional Actual Evapotranspiration of Irrigated Crops and Natural Vegetation in the Sao Francisco River Basin (Brazil) Using Remote Sensing and Penman-Monteith Equation. Remote Sensing , 2 (5), 1287-1319. https://doi.org/10.3390/rs0251287

UN - United Nations. (2015). The Millennium Development Goals Report (C. Way, Ed.). New York: United Nation.

Van Loon, A. F., \& Van Lanen, H. A. J. (2013). Making the distinction between water scarcity and drought using an observation-modeling framework. Water Resources Research , 49 (3), 1483-1502. https://doi.org/10.1002/wrcr.20147

Veldkamp, T. I. E., Wada, Y., Aerts, J. C. J. H., Doll, P., Gosling, S. N., Liu, J., .. Ward, P. J. (2017). Water scarcity hotspots travel downstream due to human interventions in the 20th and 21st century. Nature Communications , 8 (1), 1-12. https://doi.org/10.1038/ncomms15697

Vorosmarty, C. J., McIntyre, P. B., Gessner, M. O., Dudgeon, D., Prusevich, A., Green, P., .. Davies, P. M. (2010). Global threats to human water security and river biodiversity. Nature ,467 (7315), 555-561. https://doi.org/10.1038/nature09440

Voss, K. A., Famiglietti, J. S., Lo, M., de Linage, C., Rodell, M., \& Swenson, S. C. (2013). Groundwater depletion in the Middle East from GRACE with implications for transboundary water management in the Tigris-Euphrates-Western Iran region. Water Resources Research ,49 (2), 904-914. https://doi.org/10.1002/wrcr.20078

Wada, Y., Niko, Ludovicus P H, van B., Wanders, \& Bierkens, M. F. P. (2013). Human water consumption intensifies hydrological drought worldwide. Environmental Research Letters , 8 (3), 34036. https://doi.org/10.1088/1748-9326/8/3/034036

Watkins, M. M., Wiese, D. N., Yuan, D.-N., Boening, C., \& Landerer, F. W. (2015). Improved methods for observing Earth's time variable mass distribution with GRACE using spherical cap mascons. Journal of Geophysical Research: Solid Earth , 120 (4), 2648-2671. https://doi.org/10.1002/2014JB011547

WEF - World Economic Forum. (2019). The Global Risks Report 2019(14th ed.). Retrieved from http://wef.ch/risks2019

Wittenberg, H., Aksoy, H., \& Miegel, K. (2019). Fast response of groundwater to heavy rainfall. Journal of Hydrology , 571 , 837-842. https://doi.org/10.1016/j.jhydrol.2019.02.037

Xavier, A. C., King, C. W., \& Scanlon, B. R. (2016). Daily gridded meteorological variables in Brazil (1980-2013). International Journal of Climatology , 36 (6), 2644-2659. https://doi.org/10.1002/joc.4518

Xie, J., Liu, X., Wang, K., Yang, T., Liang, K., \& Liu, C. (2020). Evaluation of typical methods for baseflow separation in the contiguous United States. Journal of Hydrology , 583 , 124628. https://doi.org/10.1016/j.jhydrol.2020.124628

Yoshida, T., \& Troch, P. A. (2016). Coevolution of volcanic catchments in Japan. Hydrology and Earth System Sciences , 20 (3), 1133-1150. https://doi.org/10.5194/hess-20-1133-2016

Zemp, D. C., Schleussner, C. F., Barbosa, H. M. J., Hirota, M., Montade, V., Sampaio, G., .. Rammig, A. (2017). Self-amplified Amazon forest loss due to vegetation-atmosphere feedbacks. Nature Communications , 8 (1), 1-10. https://doi.org/10.1038/ncomms14681

Zhang, J., Zhang, Y., Song, J., \& Cheng, L. (2017). Evaluating relative merits of four baseflow separation methods in Eastern Australia.Journal of Hydrology , 549 . https://doi.org/10.1016/j.jhydrol.2017.04.004

Zipper, S. C., Dallemagne, T., Gleeson, T., Boerman, T. C., \& Hartmann, A. (2018). Groundwater Pumping Impacts on Real Stream Networks: Testing the Performance of Simple Management Tools. Water Resources Research , 54 (8), 5471-5486. https://doi.org/10.1029/2018WR022707 
Zipper, S. C., Gleeson, T., Kerr, B., Howard, J. K., Rohde, M. M., Carah, J., \& Zimmerman, J. (2019). Rapid and Accurate Estimates of Streamflow Depletion Caused by Groundwater Pumping Using Analytical Depletion Functions. Water Resources Research , 55 (7), 5807-5829. https://doi.org/10.1029/2018WR024403

\section{Table caption}

Table 1. The main features of hydrographical regions of the Sao Francisco River Basin (SFB).

Table 2. The annual trend magnitude for streamflow $\left(Q_{t}\right)$, baseflow $\left(Q_{b}\right)$ and quickflow $\left(Q_{q}\right)$ in the Sao Francisco Basin (SFB) according to river gauge. Trends were assessed using the Mann-Kendall and TheilSen's slope estimator at 0.05 of significant level.

\section{Figure caption}

Figure 1.The Sao Francisco River Basin (SFB) location and river gauges along the Sao Francisco river.

Figure 2. The spatial distribution of: (a) annual precipitation $(P),(\mathbf{b})$ evapotranspiration $(\mathrm{ET})$ and (c) climate type according to Koppen over the Sao Francisco Basin (SFB).

Figure 3. Boxplot of baseflow and streamflow of Sao Francisco River in the hydrographical regions (Upper, Middle, Sub-middle and Lower SFB) over the 1980-2015 period.

Figure 4. (a) Location of the wells. (b) Irrigation demand over the Sao Francisco River. Trend magnitude in the annual: (c) precipitation $(P),(\mathbf{d})$ evapotranspiration $(\mathrm{ET})$, and (e)terrestrial water storage change (TWS) and baseflow. Trends in baseflow along the Sao Francisco River is indicated by the grey circles. Trends were assessed using the Mann-Kendall and Theil-Sen's slope estimator at 0.05 of significant level. White color means nonsignificant trend.

Figure 5. Trend magnitude in the seasonal: $(\mathbf{a}-\mathbf{d})$ precipitation $(P),(\mathbf{e}-\mathbf{h})$ evapotranspiration $(\mathrm{ET})$, and $(\mathbf{i}-\mathbf{j})$ terrestrial water storage change (TWS) and their magnitudes over the Sao Francisco Basin. DJF $=$ December, January and February; MAM = March, April and May; JJA = June, July and August; and SON = September, October and November. Trends were assessed using the Mann-Kendall and Theil-Sen's slope estimator at 0.05 of significant level. White color means nonsignificant trend.

Figure 6. Land use and cover area according to hydrographical regions of the Sao Francisco River Basin (SFB) during 1985-2015: (a) Upper SFB,(b) Middle SFB, (c) Sub-middle SFB, and (d)Lower SFB. Land use classes were acquired from MapBiomas 3.0 (http://mapbiomas.org/).

Figure 7. Budyko curve compared to annual streamflow data (coloured circles) according to each river gauge over the 1980-2015 period. The dash line is Budyko curve based on the annual values. $P$, ET and PET are precipitation, evapotranspiration and potential ET, respectively. Where ET is computed as streamflow $\left(Q_{t}\right)$ minus precipitation $\left(\mathrm{ET}=Q_{t}-P\right)$ andPET came from the GLEAM data.

\section{Hosted file}

Table1.docx available at https://authorea.com/users/333223/articles/459793-significantbaseflow-reduction-in-the-sao-francisco-river-basin-is-it-time-to-call-for-attentionon-groundwater-withdrawals

\section{Hosted file}

Table2.docx available at https://authorea.com/users/333223/articles/459793-significantbaseflow-reduction-in-the-sao-francisco-river-basin-is-it-time-to-call-for-attentionon-groundwater-withdrawals 

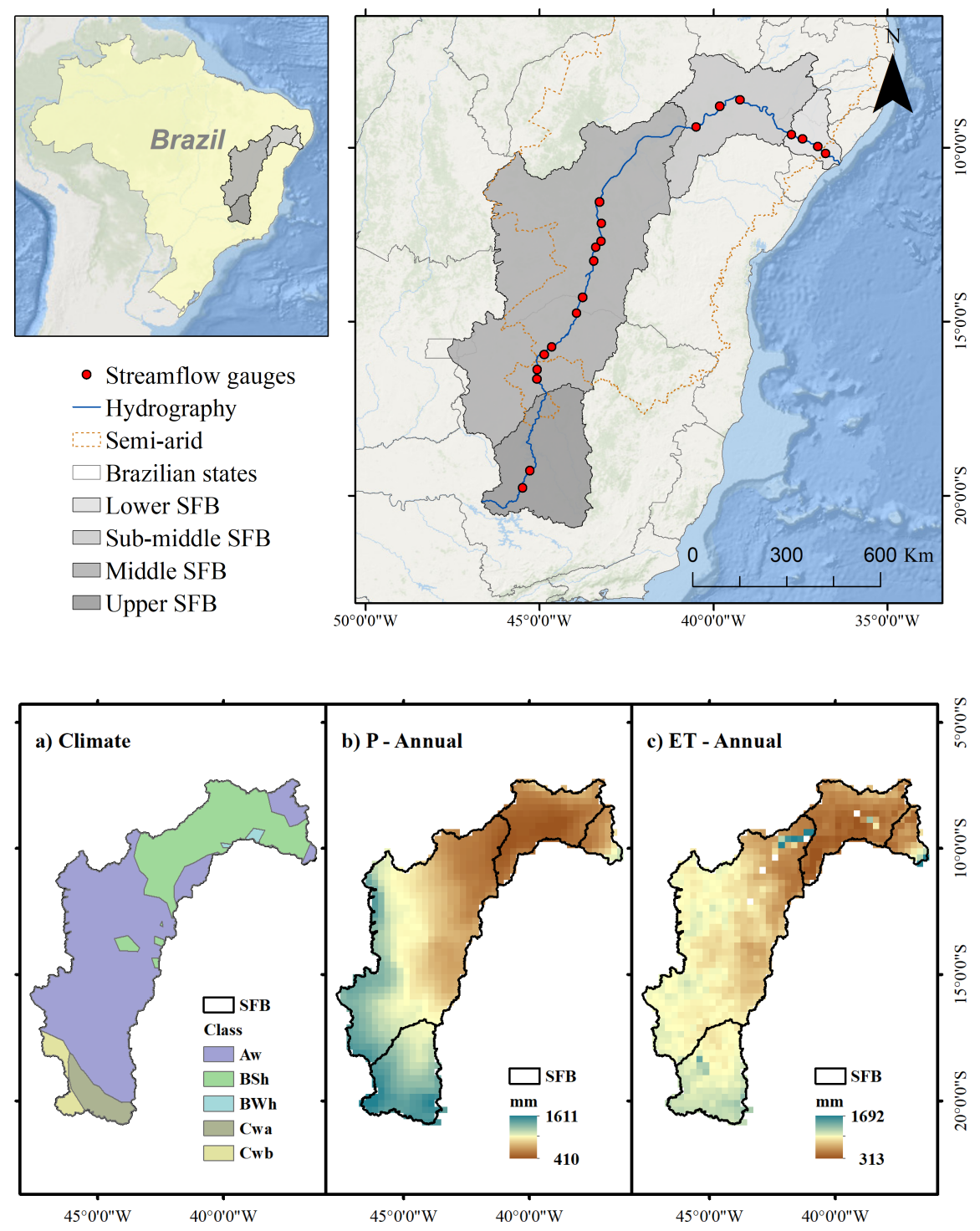






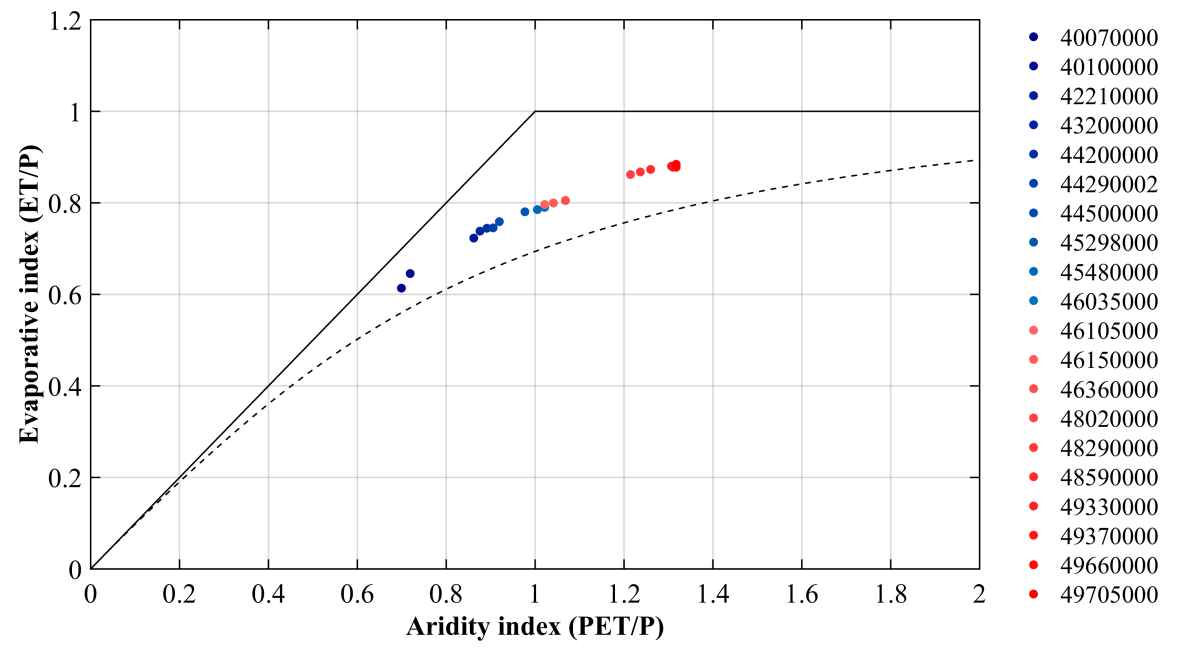

